\title{
Economic growth target and environmental regulation intensity: Evidence from 284 cities in China
}

\section{Feiyang Li}

Guangzhou Institute of Geochemistry

\section{Zhen Wang}

South China University of Technology

liangxiong Huang ( $\sim$ hlxiong@scut.edu.cn )

South China University of Technology https://orcid.org/0000-0002-9081-7967

\section{Research Article}

Keywords: Economic growth target, Environmental regulation intensity, Government work report, Endogenous

Posted Date: May 5th, 2021

DOl: https://doi.org/10.21203/rs.3.rs-442311/v1

License: (c) (1) This work is licensed under a Creative Commons Attribution 4.0 International License. Read Full License

Version of Record: A version of this preprint was published at Environmental Science and Pollution Research on September 13th, 2021. See the published version at https://doi.org/10.1007/s11356-02116269-0. 


\section{Abstract}

Management of economic growth targets is a universal measure employed by worldwide governments for macroeconomic regulation, as well as an important mechanism for central governments to motivate local governments and officials. This paper extracted panel data on annual economic growth targets and environmental regulation indicators from government work reports (2009-2016) of 284 China's prefecture-level cities to empirically investigate the impact of economic growth targets set by governments of prefecture-level cities on the environmental regulation intensity. The study concludes that an increase in economic growth targets significantly weakens the intensity of environmental regulation. The conclusion still holds true after robustness tests by changing measurement variables, regression samples and conducting endogenous tests. This also corroborates that empirical results in this study are robust. The underlying reason for the inhibitory effect may be that local governments to achieve economic growth targets prefer less stringent environmental regulations so as to expand outputs in the short term, mainly by increasing the proportion of secondary industry in GDP, land transfer area and fixed asset investment. Further research in this paper also finds that the negative effect of a local government's annual economic growth target on environmental regulation intensity only exists in cities with low economic development levels and low openness to the outside world.

\section{Introduction}

The increasingly serious ecological and environmental problems greatly hinder the future development of human beings. It is a common aspiration of mankind to maintain a pleasant living environment with blue sky, green land, green mountains and clean water. As the world's largest developing country, China has created an unprecedented miracle in economic growth over the past four decades. However, nowadays it is confronted with a bottleneck for high-quality economic development as a result of the increasingly serious ecological damage and environmental pollution, which requires China to strengthen environmental regulation. Environmental regulation is an important constituent of social regulation. Governments regulate economic activities of enterprises and other entities by formulating corresponding environmental policies and measures to achieve the goal of maintaining a coordinated development of environment and economy.

China's environmental regulation is closely related to its administrative systems, mechanisms, policies, and other factors. Economic growth target management is one of such typical systems and mechanisms. It is a major means of motivating local governments and officials and has played a critical role in the process of China's rapid economic growth for more than four decades. Moreover, it runs through the entire political system in China, applied by Party committees, administrative departments, and all levels of government from top to bottom, which has become an important phenomenon in the process of China's macroeconomic growth. In fact, the phenomenon of economic growth target management is universal around the world rather than exclusive to China. Globally, at least 49 economies have announced their economic growth targets since 1950 (Xu and Liu 2017), including developed countries such as Germany, the United Kingdom (the UK), Japan, South Korea, and developing countries such as China and India. 
Regarding goals as a core element in its government performance management system (Halpern 2015), the UK sets and implements various top-down policy objectives.

Among the countries that enforce the economic growth target management system, China is the most determined that always proactively proposes its economic growth targets and reliably boosts its economy. In China, governments at all levels announce economic growth targets in reports of the Party Congress, outlines of development planning and government work reports. Such announced targets restrict and deeply affect behaviors of local governments and officials. In the context of "political centralization and economic decentralization", GDP growth rate is still the main assessment of local governments and officials. To achieve growth targets, governments at all levels use all their powers and resources to foster economic growth. Environmental regulation is an important means of guiding or allocating various elements to certain industries or economic activities (Xu et al. 2018; Liu et al. 2019). Xu and Liu (2017) used data from 49 economies, including China that have consistently or regularly announced economic growth targets. Their empirical research found that the announced economic growth targets and subsequent economic growth rates were positively correlated. On average, when the economic growth target changes by $1 \%$, its corresponding subsequent economic growth rate also changes by about $1 \%$.

In the performance appraisal and incentive system that includes economic growth target management, local governments often pay attention to short-term economic effects, and deeply intervene in regional economic and social activities by decentralized management of economy, society, ecology, and culture. Intervention includes changing the intensity of local environmental regulations, which generally has adverse effects on the environment. Li and Chen (2019) pointed out that polluting enterprises with higher industrial outputs, larger total taxes and more employees contributed more to local economy as well as local officials' performance and had stronger bargaining power upon the implementation of environmental regulations by governments, so that the enterprises could be exempt from strict environmental regulations. These indicated that constraints of economic growth goals may have an impact on the degree of environmental regulation stringency of local governments. Therefore, this paper focusing on the effect of economic growth targets on the degree of environmental regulation stringency attempts to solve the following questions: (1) Do economic growth targets weaken environmental regulation stringency? (2) If a negative effect exists, does it have heterogeneity? (3) What is the internal mechanism of the effect? In order to empirically test these problems, this paper collects data from more than 2000 government work reports of 284 prefecture-level cities in China ranging from 2009 to 2016. This paper extracts data on government economic growth targets, constructs the environmental regulation stringency index, empirically tests the impact of local economic growth targets on the degree of environmental regulation stringency, analyzes a mechanism, and conducts heterogeneity analysis. It is found that every $1 \%$ increase in economic growth targets will reduce the degree of environmental regulation stringency by approximately $0.19 \%$. This paper further points out that local governments targeting economic growth tend to weaken environmental regulation stringency, so as to expand outputs in the short term, specifically to increase the proportion of the secondary industry in GDP, land transfer 
area and investment in fixed assets. This paper finds that the impact of local economic growth targets on environmental regulation stringency only exists in areas with underdeveloped economy or low openness.

Compared with previous studies, this paper may have innovations and contributions in the following aspects. First, this article regards the management of economic growth targets as an important system for restraining and motivating local governments and officials, and analyzes its effect on local governments' environmental regulations and its further effect on the environmental regulation intensity. When analyzing local governments and officials' impact on environmental regulation, both the environmental federalism Literature (Oates and Schwab 1988; Oates 1999; Kunce and Shogren 2005; Lai 2013), and the official "Promotion Tournament" Literature (Besley and Case 1995;Tung and Cho 2001; Zhang et al. 2020; Chen and Gao 2020) emphasized that local governments and officials tended to "race to the bottom". That is, they continuously weakened environment regulation intensity in order to achieve rapid economic growth. Nevertheless, their studies lacked the analysis on economic growth target management.In effect, as a crucial mechanism that constrains and motivates local governments and officials, management of economic growth targets changes the degree of environmental regulation intensity by affecting environmental regulation behaviors of local governments and officials.

Second, from the perspectives of economic growth target management and local officials' promotion and incentives, this paper discusses the relationship between economic growth target management and environmental regulation, providing a new perspective for the study of environmental regulation, and introducing the literature of economic growth target management to the field of environmental economics. Although many scholars have recently carried out research on the management of economic growth objectives, most of them focused on the formulation of economic growth goals (Ma 2013; Xu and Liang 2014; Yu and Yang 2017; Wang and Huang 2019; Li and Liu 2019), or the impact of economic growth goals on economic growth (Xu and Gao 2015; Xu and Liu 2017; Xu et al. 2018). Rarely have they investigated the impact of economic growth goals on non-economic growth areas and working mechanisms.

Third, despite the fact that a large amount of literature has noted that the assessment and evaluation mechanism of GDP supremacy is the direct reason for many local governments and officials' behaviors, most previous studies measured motivation and incentives of local governments and officials based on the tenure, age and promotion of officials (Zhou et al. 2017; Wang et al. 2018; Zhang and Chen 2018; Jin And Shen 2019). This paper attempts to take economic growth targets set by local governments as a new measurement to characterize local governments and officials' responses to assessment by superior governments. This new measurement can comprehensively reflect drivers of local officials' behaviors. In addition, among various indicators to measure the degree of environmental regulation intensity, most are based on post extrapolation (Gray and Deily 1996; Laplante and Rilstone 1996; Dasgupta et al. 2001; Zeng 2008; Rubashkina 2015; Zhou et al. 2017). Following the procedure employed by Chen et al. (2018), this paper collected government work reports and measured the degree of environmental regulation intensity by using the proportion of sentences containing environmental words to comprehensively investigate environmental regulation of 284 Chinese prefecture-level cities. This quantitative measure, a 
pre-analysis indicator is seldom used in environmental regulation intensity research and its relevant research is still at the exploratory stage.

The follow-up structure of this paper is as follows: the second part reviews extant research and presents a theoretical hypothesis; the third part establishes a model and elaborates on data collected; the fourth part conducts an empirical analysis; the fifth part discusses and analyzes possible mechanisms; the sixth part introduces heterogeneity tests; the last part is the conclusion of this study.

\section{Literature Review And Theoretical Hypothesis}

Environmental pollution has negative externalities and needs control by the government's environmental regulation. Environmental regulation refers to the series of regulations and policies as well as behavior standards stipulated by governments to manage, control and interfere enterprise production and operation in order to solve environmental problems and implement environmental protection strategies(Bo et al. 2018). It includes formulating and enforcing environmental regulations and policies, and adopting protective measures. Generally, there are two major environmental regulation methods: Command-and-Control and Incentive-Based (Oates et al. 1989). Stavins (2007) pointed out that there was no fixed government intervention model or independent regulation tool for environmental regulation, so that market-based and Command-and-Control environmental regulation tools could play a role.

Environmental regulation stringency can be an indicator judging the degree of importance local governments attach to environmental protection or the efforts they made to protect the environment, but it is noteworthy that the degree of environmental regulation stringency is difficult to measure in empirical analysis. Busse (2004) and Lu (2009) stated that many empirical studies were limited due to the difficulty in obtaining data relevant to environmental regulation stringency and the low data quality. Different indicators are used by different scholars. For example, Gray and Deily (1996), Laplante and Rilstone (1996) chose the number of inspections as the index of environmental regulation, while Dasgupta et al. (2001) used the pollution tax instead. Tu (2019) took the energy intensity index as the proxy variable to measure the degree of environmental regulation stringency and used the ratio of total energy consumption to total cement output as an indicator when studying environmental regulation issues in the cement manufacturing industry. Liu (2019) measured the degree of environmental regulation stringency by using the ratio of the investment in industrial pollution control to the industrial added value. Yana Rubashkina 82015 \used data on Pollution Abatement and Control Expenditures (PACE) as a proxy for environmental regulation. $\mathrm{Yi}$ et al. (2017) employed the percentage of industrial $\mathrm{SO}_{2}$ emissions to standards in a city to measure the degree of environmental regulation stringency and the effectiveness of regulation enforcement in a city. The above indicators are often inferred after facts. That is, the degree of environmental regulation stringency is judged after the occurrence of behaviors such as sewage discharge and inferred based on the results of the behaviors. However, market entities generally use the intensity of environmental regulation as constraints for their future actions and behaviors related to pollution. It is obvious that the above-mentioned indicators fail to satisfy such requirements of the market entities. Referring to the practice of Chen et al. (2018), this paper adopts a more cutting-edge approach to 
measure environmental regulation by using the proportion of sentences that contain environmental protection words. A comprehensive analysis is conducted to the manually collected data on municipal government work reports from 284 prefecture-level cities in China from 2009 to 2016. Government work reports are published before a new year. Accordingly, the approach used in this study is pre-evaluation and market entities can infer environmental regulation stringency in a new year based on the discussion on ecological environment in government work reports and make behavioral decisions.

The environmental regulation intensity affects not only environmental pollution but also economic growth that is closely related to attitudes and behaviors of governments. Yu et al. (2020) having analyzed China's provincial panel data dated from 2008 to 2018 observed that there was a long-term dynamic relationship between environmental regulation and economic growth. Less stringent environmental regulation can rapidly increase economic growth at least in the short run (Zhang 2005; Huang et al. 2012). Extensive research found that competition for GDP among local governments would result in weak environmental regulation stringency (Oates and Schwab 1988; Zhang 2005; Li et al. 2014; Zhang and Pan 2020). Moreover, scholars have noticed that the assessment and evaluation mechanism of GDP supremacy has been the direct motive for behaviors of many local governments and officials for a long time. However, most of the previous studies measured the motivation and incentive of local governments and officials based on the tenure, age and promotion of officials (Zhou et al. 2017; Wang et al. 2018; Zhang and Chen 2018; Jin and Shen 2019). Few studies have been done on economic growth target management, an important means of stimulating and restraining officials. Recently, a series of studies focused on the economic growth target management that Chinese governments enforced for economic development (Xu and Gao 2015; Xu and Liu 2017; Yu and Pan 2019). Governments at all levels formulate clear economic growth goals in five-year plans for national economic and social development as well as government work reports to guide economic construction in their districts. Economic growth targets are not only a critical means for Chinese governments at higher levels to motivate and manage officials in lower echelon (Wang and Wang 2009; Zhou et al. 2015), but also a major tool for local officials to achieve more economic and financial benefits and demonstrate positive information such as their capabilities and loyalties to higher authorities.

Literature on management of economic growth targets is essentially a continuation of the "Official Promotion Tournament" theory. Since the reform and opening up, China has reformed the cadre and personnel system and established an effective incentive mechanism for the evaluation and promotion of local officials. The measurable "View of Political Achievements" based on local economic development provides driving force for China's economic development. Zhang (2005) emphasized the importance of "Competing for Growth" in understanding China's economic growth. Referring to the definition of tournament, Zhou (2007) put forward the concept of "Promotion Tournament" and discussed its significance in understanding China's rapid economic growth and various unique problems. However, this study mainly emphasized the horizontal competition among local officials but ignored the "Vertical Competition" of the officials themselves. Problems still persist. For example, how do local officials set and achieve economic growth goals that are in agreement with the targets set by the central government and that can make them stand out from their counterparts? Through an empirical analysis on the influence of 
the provincial governors' promotion incentives on the level of provincial economic growth targets, $\mathrm{Ma}$ (2013) concluded that the relationship between the tenure of officials and the level of economic growth targets is U-shaped and that locally promoted officials tended to set higher economic growth targets. Zhou et al. (2015) examined the "layer by layer increase" phenomenon of economic growth targets from the central government to grassroots governments and revealed that this phenomenon was closely related to promotion incentives of local officials. Xu and Liang (2014) observed that when the central government turned to adjust the regional economic pattern and adopted a wide range of economic policies in favor of underdeveloped areas, the local governments in developed regions would strategically lower economic growth targets.

In fact, economic growth targets impose constraints and pressures on officials. Local governments establish economic growth targets based on three primary factors (Wang and Huang 2019). First, targets directly reflect the will of government leaders. "Economic Decentralization" allows local officials to have moderate authority for self-decision as well as action, and a better understanding of the actual situation of the locality (Ma 2013; Yu and Yang 2017). Second, target establishment also mirrors the will of senior governments to a certain extent. In the framework of "Political Centralization", local officials have to respond to targets and tasks assigned by senior governments that take control of these officials' political future, leading to the phenomenon of "Layer by Layer Increase" (Zhou et al. 2015; Li et al. 2019). Li and Liu (2019) proposed that senior officials used economic growth targets to express the significance of economic growth and motivate their subordinates in tournament. Third, target setting is also affected by other areas of the same level. Under the governance mode of promotion tournament, there is fierce horizontal competition among local officials (Fu and Qiao 2011; Huang et al. 2015). Governments led by the same senior government take strategies of their counterparts into account when formulating local economic growth targets. That is, there is an interaction between targets of regions at the same level.

According to existing research, governments' economic growth targets do effectively promote economic growth (Xu and Gao 2015; Sun and Liu 2016; Xu and Liu 2017), given that governments are authorized to freely allocate various resources, such as financial funds, land, and state-owned enterprises, and are capable to make good use of various means and tools to achieve the targets. Environmental regulation is one of the significant means. Generally, local governments enjoy certain autonomy in their environmental policies. In the assessment system with GDP as the core, local governments create economic growth by encouraging investment at the cost of environmental destruction. Many scholars focused on the regional competition in environmental policies (regulations). Millimet (2003) proposed that there was a horizontal strategic interaction among local governments in the United States. In the resource competition mode, local governments may use more than one means to attract enterprises, which induces strategic interaction between policy instruments. Yang et al. (2008) believed that under the current concept of political performance, local governments competed in environmental policies. That is, when one province reduced environmental standards, other provinces would also decrease their standards. Li and Shen (2008) held similar views and emphasized that Chinese local governments' decision on pollution control has obvious strategic characteristics that pollution levels of a region and its neighboring areas are positively correlated. This phenomenon is called "race to the bottom" proposed by environmental 
federalism. Local governments with limited financial resources find it difficult to provide a better infrastructure and institutional environment and to compete against their counterparts that have comparable strength. Therefore, the governments employ unconventional means of competition such as lowering environmental and safety standards to attract investment (Oates and Schwab 1988; Zhang 2005), resulting in environmental deterioration and frequent environmental accidents (Li 2009). Li et al. (2014) proposed that under the performance appraisal mechanism in which economic growth was the core competition goal, local governments tended to sacrifice ecological environment to gain short-term economic benefits. Specifically, they raced to decline the level of environmental regulation, giving rise to weak coordination between regional economy and environment. Such behavior was like drinking poison to quench thirst. Qin and Shen (2020) believed that competition among local governments under the influence of environmental regulation has weakened the stimulation to total factor productivity (TFP). In addition, governments tend to sacrifice environmental quality for economic benefits. Wang and Feng (2014) found that strengthening environmental regulation indeed led to the decline of some economic indicators in the short term and a certain negative impact, which was out of favor with local governments. Wang et al. (2020) further pointed out that environmental regulation could inhibit social employment in the short term but promoted social employment in the long term. In the GDP-oriented performance appraisal system, the government concentrates more attention to short-term employment.

In relation to government goals, Hong et al. (2019) proposed the asymmetric incentive mechanism in which local government officials gave priority to economic growth goals over environmental quality. Zhang and Pan (2020) examined the theoretical connection between China's environmental goals and GDP growth goals. Their study regarding environmental protection and economic development as China's competition task concluded that environmental goals constrained GDP growth goals, and that this negative correlation was weakened by relative pollutant emission efficiency. Furthermore, some articles pointed out that officials at different positions had distinct impact on resource depletion and urban environmental pollution. Municipal Party committee secretaries had a greater dynamic effect on environmental pollution than mayors, and had more robust effect (Zhang et al., 2017).

To sum up, the following hypothesis is put forward:

Hypothesis: The improvement of local economic growth targets significantly reduces the degree of environmental regulation stringency.

\section{Data And Model}

\section{Empirical model setting}

In order to test the impact of economic growth targets on the degree of environmental regulation stringency, the following regression equation is set: see equation 1 in the supplementary files.

where $i$ denotes the city and $t$ is the year. Renv denotes the index of environmental regulation stringency, and target is the economic growth target of a city. Taking account of the lag of the social impact of the 
government's economic policies, this paper refers to the practices of Wang et al. (2020) and Ren and Matsumoto(2020) to examine the effect of lag period of independent variables on dependent variables. On this basis, we further take the lag phase of the economic growth target as an independent variable. $X$ denotes other control variables, and $\varepsilon$ is a random disturbance term. When the regression of equation (1) was carried out, the fixed effect model was adopted for estimation.

The coefficient $\beta$ is the regression coefficient of the greatest concern in this paper. Its symbol and magnitude measure the impact of economic growth targets on the environmental regulation intensity. If the coefficient $\beta$ is significantly greater than 0 , an increase in economic growth targets leads to more stringent environmental regulation in the region. If the coefficient is significantly less than 0 , an increase in economic growth targets leads to less stringent environmental regulation. If the coefficient is neither significantly greater nor less than 0 , economic growth targets has no effect on regional environmental regulation. If the hypothesis in this paper is correct, the coefficient is significantly less than 0.

\section{Data}

This article sampled China's prefecture-level cities, and the sample ranges from 2009 to 2016. Among them, the number of prefecture-level cities from 2009 to 2010 was 282, and the number of prefecture-level cities from 2011 to 2016 was 284.

The environmental regulation intensity index (Renv) is the dependent variable. Following a procedure adapted from Chen et al. (2018), this paper measures environmental regulation intensity with the proportion of sentences that contain environmental words, and obtains relevant data by manually collecting work reports of municipal governments in China. From the work reports, we select all of the sentences that contain one or more keywords such as environment (huanjing), energy consumption (nenghao), pollution (wuran), emission reduction (jianpai), and environmental protection (huanbao) as environment-related sentences.

A core independent variable is the economic growth target (target). Following the procedure detailed in $\mathrm{Li}$ et al. (2019) and Liu et al. (2019), this study employs the economic growth rate targets announced in work reports of the prefecture-level city governments. Each city generally announces its targets for economic growth rates approved by its people's congress at the beginning of each year. The economic growth target data in this article are manually collected from two channels. One is the portal websites of the People's governments of provinces and prefecture-level cities, the main source of government work reports. The other is the prefecture-level city yearbooks where work reports are published marked as "special publication". After collection, this article further processes the data on economic growth targets as follows: targets that are explicit numbers or followed by modifiers such as "about", "around", "above", "higher", "minimum", and "not less than", are counted using the referred numbers; for economic growth target interval, a mean value is used.

In addition to core variables, this article takes a series of control variables into account in the empirical regression. We select the following control variables: the real GDP per capita (Ipgdp), proportion of retail 
sales of consumer goods in GDP (Rcum), and proportion of foreign direct investment (FDI) to GDP (Rfdi) to measure the level of economic development, consumption power, and openness of a region respectively. Research by Zhao et al. (2015) showed that changes in the industrial structure would bring about changes in the driving force of economic growth. Therefore, we measure the industrial structure (stru) by the proportion of the secondary industry in GDP. Wang (2014) found that urbanization was the vital driving force for the stable and rapid development of China's economy because urbanization as an essential component of the national development strategy accelerated the transformation of economic development mode. Consequently, this article regards urbanization as a control variable and measures it by the ratio of the population in a municipal district to the total population of the city $(R u b)$. The article referring to the method adopted by Liu and Kong (2020) selects the logarithmic form of industrial sulfur dioxide emissions (ISO2) as a control variable. The above data are from the "China City Statistical Yearbook". Table 1 reports the descriptive statistics of main variables.

Table 1 Descriptive statistics of main variables.

\begin{tabular}{|lllllll|}
\hline Symbol & Variable name & $\begin{array}{l}\text { Number of } \\
\text { samples }\end{array}$ & Mean & $\begin{array}{l}\text { Standard } \\
\text { error }\end{array}$ & Minimum & Maximum \\
\hline L.target & $\begin{array}{l}\text { Economic growth target of } \\
\text { the previous period }\end{array}$ & 1738 & 11.640 & 2.753 & 1.500 & 26.000 \\
\hline Renv & $\begin{array}{l}\text { Environmental regulation } \\
\text { (logarithmic form) }\end{array}$ & 2161 & 1.595 & 0.447 & -1.079 & 2.733 \\
\hline Ipgdp & $\begin{array}{l}\text { Initial GDP per capita } \\
\text { (logarithmic form) }\end{array}$ & 2156 & 10.466 & 0.717 & 8.3908 & 13.135 \\
\hline Rcum & $\begin{array}{l}\text { Consumer goods retail } \\
\text { sales / GDP }\end{array}$ & 2154 & 0.361 & 0.102 & 0.001 & 0.774 \\
\hline Stru & $\begin{array}{l}\text { Urbanization rate } \\
\text { Rfdi }\end{array}$ & 2159 & 35.335 & 36.723 & 4.370 & 100.000 \\
\hline Secondary industry output & 2157 & 49.480 & 10.170 & 14.950 & 89.340 \\
\hline value/GDP & $\begin{array}{l}\text { FDI/GDP } \\
\text { Industrial sulfur dioxide } \\
\text { emissions (logarithmic } \\
\text { form) }\end{array}$ & 2084 & 11.187 & 1.577 & 0.693 & 14.569 \\
\hline
\end{tabular}

\section{Empirical Results}

\section{Benchmark result}

Table 2 reports the baseline regression results based on the empirical equation (1). The coefficients on economic growth targets in all five columns are significantly negative at the $1 \%$ level, which is consistent with the theoretical hypothesis that an increase in local economic growth targets weakens environmental regulation intensity. Specifically, column (1) of Table 2 has only one independent variable, the growth 
target variable whose coefficient is -0.261 , statistically significant at the $1 \%$ level. Different control variables are introduced in columns (2) to (5) where coefficients on economic growth targets are also significantly negative at the $1 \%$ level. The economic growth target in column (5) is -0.188 , which means that for every 1\% increase in the local economic growth target between 2009 and 2016, the level of environmental regulatory intensity will descend by roughly $0.188 \%$.

Table 2 Basic regression results.

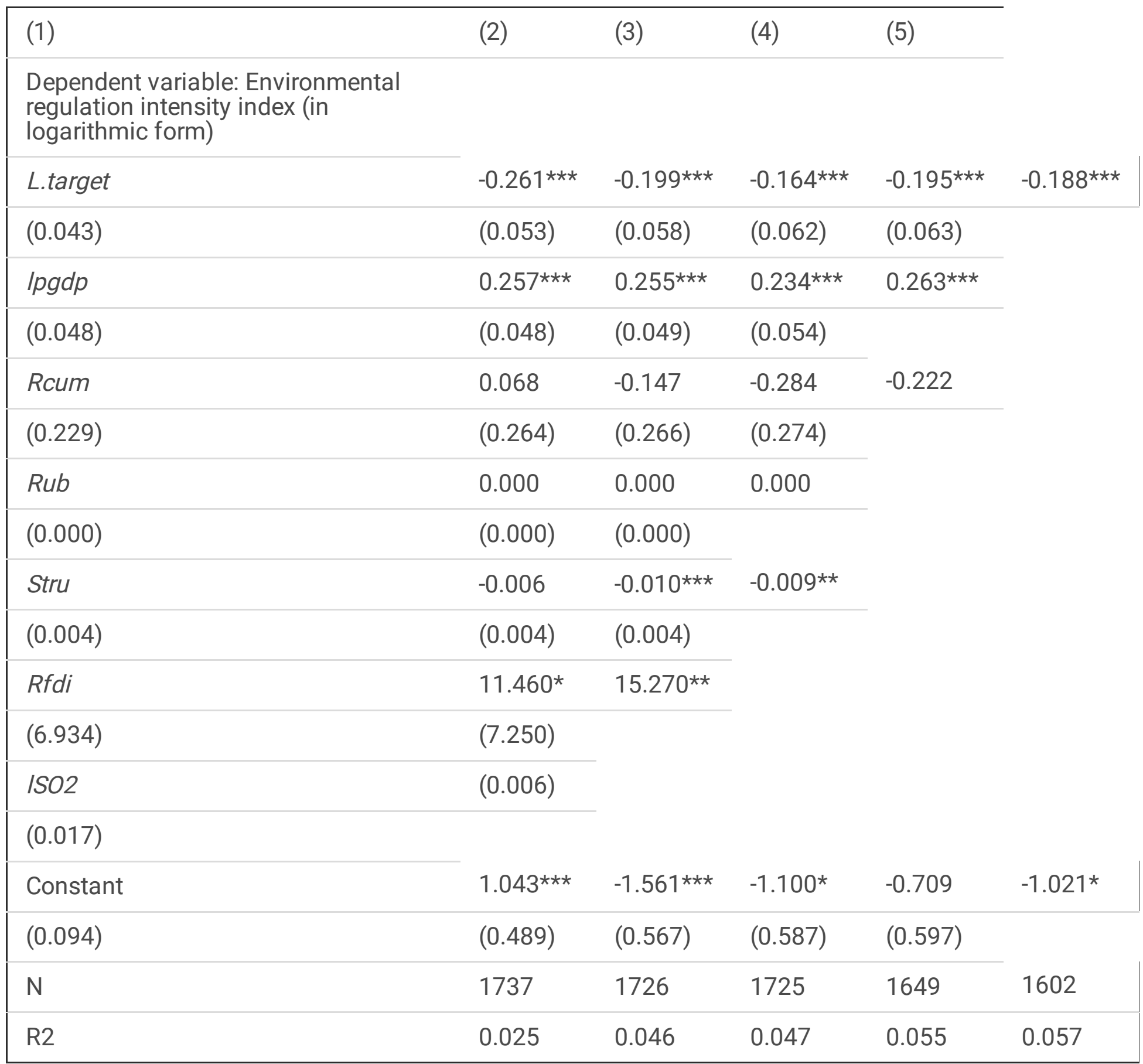

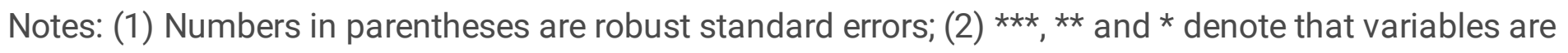
statistically significant at $1 \%, 5 \%$ and $10 \%$ respectively;(3) $\mathrm{N}$ is the number of observations and $\mathrm{R} 2$ is the goodness of fit. 


\section{Robustness test}

Table 2 presents that higher economic growth targets weaken local environmental regulation intensity. The paper adopts the following three approaches to examine robustness of the empirical results: to transform core variables, transform regression sample and test for endogenous.

Transform core variables

Measures of environmental regulation intensity and economic growth target are transformed for robustness tests. First, the measure of environmental regulation intensity is changed. The environmental protection words per capita (logarithmic form) is used in column (1) of Table 3 to measure the environmental regulation intensity. The regression coefficient on the core independent variable economic growth target is -0.205 and passes the statistical test with a significance level of $1 \%$. Column (2) includes the ratio of environmental protection words to GDP (logarithmic form) as a proxy measure of environmental regulation intensity. The coefficient on economic growth target is still significantly negative at the $1 \%$ level. This is in accordance with the conclusion we draw from the results in Table 2. Though an alternative indicator is adopted to measure the environmental regulation intensity, the conclusion that an increase in economic growth targets reduces environmental regulation intensity still holds true.

Second, the measure of economic growth targets is changed. Column (3) of Table 3 uses the "average of economic growth target indicators for two consecutive years" (logarithmic form) to measure economic growth targets, and its coefficient is significantly negative at the $1 \%$ statistical level; column (4) adopts the "average of the economic growth targets in three consecutive years" (logarithmic form) to measure the economic growth target, and its coefficient is -0.928 and passes the statistical test with a significance level at $1 \%$. Though the measurement indicator of economic growth target is changed, the conclusion that an increase in economic growth targets reduces environmental regulation intensity is still valid, which is consistent with the theoretical hypothesis.

Table 3 Robustness Test I: Transform core variables 


\begin{tabular}{|c|c|c|c|c|}
\hline (1) & (2) & (3) & (4) & \\
\hline $\begin{array}{l}\text { Dependent } \\
\text { variable }\end{array}$ & $\begin{array}{l}\text { Environmental } \\
\text { protection words per } \\
\text { capita (logarithmic } \\
\text { form) }\end{array}$ & $\begin{array}{l}\text { Environmental } \\
\text { protection words } \\
\text { /GDP(logarithmic } \\
\text { form) }\end{array}$ & $\begin{array}{l}\text { Environmental } \\
\text { Regulation intensity } \\
\text { Index (logarithmic form) }\end{array}$ & \\
\hline L.target & $-0.205^{\star \star \star}$ & $-0.205^{\star \star \star}$ & & \\
\hline$(0.063 \rrbracket$ & (0.063】 & & & \\
\hline L.target2 & $-0.451^{\star \star \star}$ & & & \\
\hline (0.141) & & & & \\
\hline L.target3 & $-0.928 * \star \star *$ & & & \\
\hline$(0.265 \rrbracket$ & & & & \\
\hline$N$ & 1602 & 1602 & 1742 & 1603 \\
\hline R2 & 0.051 & 0.161 & 0.05 & 0.056 \\
\hline
\end{tabular}

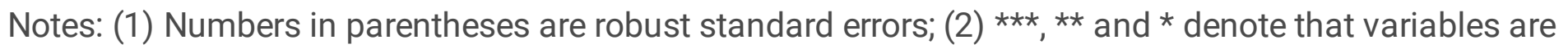
statistically significant at $1 \%, 5 \%$ and $10 \%$ respectively;(3) $\mathrm{N}$ is the number of observations and $\mathrm{R} 2$ is the goodness of fit.

\section{Transform regression sample}

Data on economic growth targets is missing to different degrees in sampled prefecture-level cities. Only 37 cities reported economic growth targets each year during the period we are examining (2009-2016), with a sample size of 592 , accounting for $13.1 \%$. The sample size of cities with partial available economic growth target data is 3901 , accounting for $86.3 \%$; the growth target data of Jiamusi, Bijie and Tongren is all missing, with a total sample size of 28 , accounting for $0.62 \%$.

Column (1) of Table 4 reports the regression results of a sample of cities with missing data on targets. The regression coefficient on the economic growth target is -0.180 and statistically significant at the $1 \%$ level. Column (2) further examines the samples of prefecture-level cities with 4 or more economic growth targets. The results show that the regression coefficient on the economic growth target is -0.188 , statistically significant at the $1 \%$ level. There is almost no difference in the regression results of the cities with missing growth target data. Column (3) examines a sample of cities with 6 or more economic growth targets. The regression coefficient on the economic growth target is -0.178 , also statistically significant at the $1 \%$ level.

The above analysis demonstrates that regardless of sample ranges, results are still in accordance with the theoretical hypothesis. From 2009 to 2016, the way China's local governments promote economic growth will have a negative impact on environmental regulation intensity. Specifically, for every $1 \%$ 
increase in the economic growth target, the environmental regulation intensity index will significantly decrease by about $0.18 \%$.

Table 4 Robustness Test II: Transformation Sample

\section{(1)}

Dependent variable: environmental regulation intensity index (logarithmic form)

\begin{tabular}{|c|c|c|c|}
\hline L.target & $-0.180 * \star \star *$ & $-0.188 * \star \star *$ & $-0.178 * \star \star *$ \\
\hline (0.065) & $(0.063)$ & $(0.063)$ & \\
\hline Ipgdp & $0.289 * \star \star$ & $0.263^{\star \star \star}$ & $0.272^{\star * \star}$ \\
\hline$(0.056)$ & $(0.054)$ & $(0.054)$ & \\
\hline Rcum & -0.149 & -0.222 & -0.375 \\
\hline (0.284) & $(0.274)$ & $(0.274)$ & \\
\hline$R u b$ & 0.000 & 0.000 & 0.000 \\
\hline$(0.000)$ & $(0.000)$ & $(0.000)$ & \\
\hline Stru & $-0.008^{*}$ & $-0.009 * \star$ & $-0.011 * * \star$ \\
\hline (0.004) & (0.004) & $(0.004)$ & \\
\hline Rfdi & $14.100 *$ & $15.270 * \star$ & $15.130 * \star$ \\
\hline (7.337) & $(7.250)$ & $(7.202)$ & \\
\hline ISO2 & 0.015 & -0.006 & -0.007 \\
\hline (0.017) & $(0.017)$ & $(0.017)$ & \\
\hline Constant & $-1.275^{\star \star}$ & $-1.021^{\star}$ & -0.913 \\
\hline (0.612) & $(0.597)$ & $(0.594)$ & \\
\hline$N$ & 1487 & 1602 & 1586 \\
\hline R2 & 0.058 & 0.057 & 0.059 \\
\hline
\end{tabular}

Notes: (1) Numbers in parentheses are robust standard errors; (2) $* \star \star, * \star$ and * denote that variables are statistically significant at $1 \%, 5 \%$ and $10 \%$ respectively;(3) $\mathrm{N}$ is the number of observations and $\mathrm{R} 2$ is the goodness of fit.

Endogenous 
The lag period of economic growth targets is taken into account in the regression model of this paper. We believe that economic growth targets are established prior to environmental regulation behaviors. Generally speaking, local governments weaken environmental regulation intensity to improve fixed asset investment and land transfer areas so as to promote economic growth and achieve the established growth targets. However, an endogenous problem cannot be ruled out because economic growth targets may be established to assess the intensity of potential environmental regulations.

This article uses instrumental variables to investigate the above-mentioned endogenous problem. Specifically, provincial economic growth targets are regarded as an instrumental variable of prefecturelevel economic growth targets (Liu et al. 2019; Yu et al. 2019), given that lower-level governments in China under the system of official promotion tournaments tend to formulate economic growth targets higher than those proposed by higher-level governments (Zhou et al. 2015), and that economic growth targets set by higher-level governments are expected to be less affected by those set by lower-level governments.

Table 5 reports the two-stage IV estimation results with provincial economic growth targets as an instrumental variable of prefecture-level economic growth targets. Column (2) reports the regression results of the first stage. The regression coefficient on the instrumental variable, provincial economic growth target is 0.308 and passes the statistical significance test of $1 \%$. This suggests that there is a significant positive correlation between economic growth targets and the instrumental variable. Column (1) reports the basic results of the second stage, IV estimation. The regression coefficient on the growth target is -0.280 and passes the statistical significance test of $5 \%$. The above results implies that the benchmark results of this article still exist when endogenity is taken into account, which corroborates the robustness of the basic conclusions.

Table 5 Robustness test III: IV regression results 


\begin{tabular}{|c|c|c|}
\hline (1) & $(2)$ & \\
\hline \multirow[t]{2}{*}{ Dependent variable } & $\begin{array}{l}\text { Environmental regulation intensity } \\
\text { index }\end{array}$ & $\begin{array}{l}\text { Prefecture-level economic growth } \\
\text { target }\end{array}$ \\
\hline & (logarithmic form) & (logarithmic form) \\
\hline $\begin{array}{l}\text { Second stage regression } \\
\text { results }\end{array}$ & First stage regression results & \\
\hline $\begin{array}{l}\text { Prefecture-level economic } \\
\text { growth targets }\end{array}$ & $-0.280 * \star$ & \\
\hline (Logarithmic form) & $(0.134)$ & \\
\hline $\begin{array}{l}\text { IV『Provincial economic } \\
\text { growth targets }\end{array}$ & $0.308^{* \star *}$ & \\
\hline (Logarithmic form) & $\varangle 0.099 \rrbracket$ & \\
\hline Constant & $-1.100^{\star}$ & -0.290 \\
\hline$(0.600)$ & $(0.244)$ & \\
\hline N & 1602 & 1602 \\
\hline R2 & 0.466 & 0.184 \\
\hline
\end{tabular}

Notes: (1) Numbers in parentheses are robust standard errors; (2) ***, ** and * denote that variables are statistically significant at $1 \%, 5 \%$ and $10 \%$ respectively;(3) $\mathrm{N}$ is the number of observations and $\mathrm{R} 2$ is the goodness of fit.

\section{Mechanism analysis}

It can be concluded from the above empirical results that an increase in local economic growth targets will significantly reduce environmental regulation intensity. In this part, we attempt to explore the functional mechanism. We believe that the significant impact of economic growth targets on environmental regulation intensity can be explained by that less stringent environmental regulation promote outputs in the short term and increase economic growth. Obviously, less strict environmental regulation can improve the proportion of the secondary industry in GDP, expand land transfer areas, and increase the growth rate of fixed asset investment. These are important measures for economic growth in the short term. In order to further verify this mechanism, the article uses the real GDP growth rate, proportion of secondary industry added value in GDP, land transfer area and fixed asset investment growth rate as dependent variables, and the environmental regulation intensity index as an independent variable for empirical testing.

The column (1) of table 6 takes the real GDP growth rate (logarithmic form) as a dependent variable, and the environmental regulation intensity index(logarithmic form) as an independent variable. The 
coefficiens on environmental regulation intensity (Renv) is negative, and at least are statistically significant at $10 \%$. The coefficients on environmental regulation intensity is -0.207 . When the intensity of environmental regulations is reduced by $1 \%$, the real GDP growth rate will increase by $0.207 \%$. This is an important reason why an increase in economic growth targets leads to a drop in the environmental regulation intensity. In order to achieve higher economic growth targets, local governments are more likely to employ their power and resources to weaken environmental regulation intensity and achieve a relatively high economic growth rate in the short term.

Table 6 Mechanism Discussion

\begin{tabular}{|c|c|c|c|c|}
\hline (1) & (2) & (3) & (4) & \\
\hline $\begin{array}{l}\text { real GDP } \\
\text { growth rate }\end{array}$ & $\begin{array}{l}\text { added value of secondary } \\
\text { industry /GDP }\end{array}$ & $\begin{array}{l}\text { area of land } \\
\text { transfer }\end{array}$ & $\begin{array}{l}\text { growth rate of investment } \\
\text { in fixed assets }\end{array}$ & \\
\hline Renv & $-0.207^{\star}$ & $-0.891 * * \star$ & $-0.054^{\star}$ & $-0.078 * \star$ \\
\hline$(0.117)$ & $(0.188)$ & $(0.030)$ & (0.039) & \\
\hline Ipgdp & $-6.039 * \star \star$ & $0.712^{\star \star *}$ & $0.153^{\star \star \star}$ & 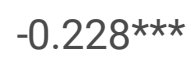 \\
\hline$(0.202)$ & $(0.325)$ & $(0.048)$ & $(0.079)$ & \\
\hline Rcum & $-12.000 * \star *$ & $-47.220 * \star \star$ & $-1.348^{\star \star \star}$ & -0.573 \\
\hline (1.127) & (1.399) & $(0.293)$ & $(0.385)$ & \\
\hline Rub & 0.000 & $-0.005^{\star \star}$ & 0.000 & 0.000 \\
\hline$(0.001)$ & $(0.002)$ & $(0.000)$ & $(0.000)$ & \\
\hline Stru & $0.179 \star \star \star *$ & $0.038 * \star \star *$ & $0.011^{* \star}$ & \\
\hline$(0.015)$ & $(0.004)$ & $(0.005)$ & & \\
\hline$R f d i$ & 0.052 & $2.700 \star \star \star *$ & $0.213^{* * *}$ & 0.075 \\
\hline$(0.316)$ & $(0.503)$ & $(0.076)$ & $(0.123)$ & \\
\hline ISO2 & -0.075 & $0.293^{* * *}$ & $0.072^{\star \star \star *}$ & $-0.058 * \star$ \\
\hline$(0.064)$ & $(0.102)$ & $(0.015)$ & $(0.023)$ & \\
\hline Constant & $70.860 * \star \star$ & 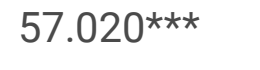 & $2.705^{\star \star \star}$ & 1.050 \\
\hline (1.961) & $\llbracket 2.834)$ & -0.471 & $(0.826)$ & \\
\hline $\mathrm{N}$ & 1970 & 1974 & 1713 & 1485 \\
\hline R2 & 0.611 & 0.434 & 0.223 & 0.056 \\
\hline
\end{tabular}

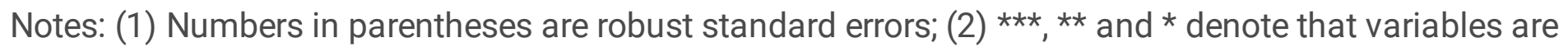
statistically significant at $1 \%, 5 \%$ and $10 \%$ respectively;(3) $\mathrm{N}$ is the number of observations and $\mathrm{R} 2$ is the 
goodness of fit.

Under Chinese "political centralization and economic decentralization" system, local governments have great authority to intervene in economic activities of market entities such as intervening in business operation of state-owned enterprises and adjusting prices of minerals, energy as well as other resource factors to significantly increase the second industrial outputs, thereby boosting economic growth. Lin (2007) believed that China's economic growth in recent decades has been driven mainly by capital and land inputs with low interest rates and low prices of energy, resources and other factors. The unreasonable factor price system was the root of China's factor-driven economic growth model. Xu et al. (2007) pointed out that competition among provincial officials has led local officials to vigorously develop second industries to increase economic growth. For this reason, the column (2) of table 6 takes the proportion of second industry added value to GDP as a dependent variable and the environmental regulation intensity index as a core independent variable. Similarly, the coefficient on environmental regulation intensity (Renv) is statistically significant at the $1 \%$ level, suggesting that less stringent environmental regulation significantly increases the proportion of the secondary industry. Increasing the proportion of the secondary industry can achieve high economic growth rates in the short term.

Land resources are the most basic production factor for economic development, and local governments in China play a decisive role in the supply of industrial land. Local governments regard the efficient allocation of industrial land as an important means of promoting local economic development and GDP growth (Yang, 2020). Zhang et al. (2013) pointed out that as land was an important resource controlled by local governments, local officials might tend to sell large amounts of land for the purpose of economic development.

Stringent environmental regulation actually restricts the use of land resources by local governments, which in turn affects the rate of local economic growth. Less stringent environmental regulation allows local governments to utilize land resources for the construction of new projects, including projects that cause pollution to the environment. From this perspective, the intensity of environmental regulations is closely related to the area of land sold by local governments. Therefore, the article takes the area of land transfer (logarithmic form) as a dependent variable and the environmental regulation intensity as a core independent variable to further test the impact of the intensity of environmental regulations on the area of land transfer (see column (3) of table 6). The coefficient on environmental regulation intensity (Renv) is -0.054 , statistically significant at the $10 \%$ level. These result suggests that less stringent environmental regulation bring about an increase in the area of land for sale, thereby boosting economic growth. The research by Hu and Lv (2019) found that raising economic growth targets remarkably expanded the area of land transfer, in accord with our findings. Hence, it can be concluded that when local governments set higher economic growth targets, they intentionally weaken environmental regulation stringency so as to increase the area of land transfer within their jurisdiction and to achieve short-term expansion of outputs.

Fixed asset investment is the main driving force for China's economic growth. Economists such as the Nobel Prize winner Krugman and Alwyn Young from the London School of Economics believed that 
China's economic boom is not a miracle since its growth model is "high input and low efficiency". Although the GDP growth rate is high, the total factor growth rate is only $2 \%$ to $3 \%$, equal to the long-term total factor productivity in developed countries. When establishing high economic growth targets, Chinese local governments have a strong internal driving force to increase fixed asset investment on a large scale in order to achieve such economic growth targets. Liu et al. (2019) also argued that local governments used their power and resources to increase investment in fixed assets so as to achieve economic growth goals. However, environmental regulations restrict local governments' increase in fixed asset investment. In order to improve the growth rate of fixed asset investment, local governments will intentionally weaken the intensity of environmental regulations to be exempt from constraints on fixed investment increase. From this perspective, the growth rate of local government's fixed investment is closely related to environmental regulation intensity.

Therefore, the article takes the growth rate of fixed asset investment (logarithmic form) as a dependent variable and the environmental regulation intensity as the core independent variable to further empirically test the influence of environmental regulation intensity on fixed asset investment. The empirical test results demonstrate that regardless whether control variables are added or not, the regression coefficients on the degree of environmental regulation intensity (Renv) are statistically significant at the $5 \%$ level (see column(4) of table 6), suggesting that weakened intensity of environmental regulations significantly increase investment in fixed assets, which is consistent with the research results made by Oates and Schwab (1988) and Zhang (2005). Hence, it can be concluded that local governments faced with high economic growth targets intentionally weaken the intensity of environmental regulation, so as to increase the fixed asset investment in the jurisdiction for short-term expansion of outputs.

\section{Heterogeneity analysis}

So far, the empirical test results of this article are consistent with the theoretical hypothesis expectations. From 2009 to 2016, the increase in economic growth targets set by local governments significantly reduces the degree of environmental regulation stringency. The purpose of weakening the intensity of environmental regulations is to expand outputs in the short term, specifically to increase the proportion of the secondary industry in GDP, the area of land transferred by the government, and investment in fixed assets. This section will further explore whether there is heterogeneity for the effect of economic growth targets on environmental regulation stringency under different conditions, aiming to further reveal the underlying mechanism.

\section{The heterogeneity of urban development}

The degree of urban development is measured by real GDP per capita. According to the size of real GDP per capita, samples are divided into two groups and regression is performed to both groups. Cities with a real GDP per capita higher than the mean value are regarded as developed whereas those lower than the mean value as less developed. Column (1) of Table 7 presents samples of less developed cities where the regression coefficient on the economic growth target is -0.227 and statistically significant at the $5 \%$ level. Column (2) of Table 7 shows samples of developed regions where the coefficient on the economic growth 
target is insignificant. The above results indicate that a fall in the degree of environmental regulation stringency resulted from an increase in economic growth targets only occurs in underdeveloped areas.

Table 7 Analysis of Heterogeneity I: Degree of Urban Development.

\begin{tabular}{|c|c|c|}
\hline घ10 & \multicolumn{2}{|l|}{$\nabla 2 \rrbracket$} \\
\hline $\begin{array}{l}\text { Dependent variable: environr } \\
\text { (logarithmic form) }\end{array}$ & \multirow[b]{2}{*}{$\begin{array}{l}\text { Developed area } \\
\text { group }\end{array}$} & \multirow[b]{3}{*}{-0.060} \\
\hline Underdeveloped area group & & \\
\hline L.target & $-0.227 \star \star$ & \\
\hline$(0.101)$ & $(0.086)$ & \multirow[b]{2}{*}{$0.316^{* \star \star}$} \\
\hline Ipgdp & $0.197 * \star$ & \\
\hline$(0.089)$ & $(0.092)$ & \multirow[b]{2}{*}{0.570} \\
\hline Rcum & -0.407 & \\
\hline$(0.360)$ & $(0.495)$ & \multirow[b]{2}{*}{0.000} \\
\hline Rub & 0.000 & \\
\hline 0.000 & $(0.000)$ & \multirow[b]{2}{*}{-0.008} \\
\hline Stru & -0.006 & \\
\hline$(0.006)$ & $(0.006)$ & \multirow[b]{2}{*}{$16.230^{\star}$} \\
\hline Rfdi & 16.170 & \\
\hline$(16.330)$ & $(8.347)$ & \multirow[b]{2}{*}{-0.038} \\
\hline ISO2 & 0.013 & \\
\hline$(0.024)$ & $(0.026)$ & \multirow[b]{2}{*}{-1.287} \\
\hline Constant & -0.692 & \\
\hline$(0.845)$ & $(1.185)$ & \multirow[b]{2}{*}{850} \\
\hline $\mathrm{N}$ & 752 & \\
\hline R2 & 0.034 & 0.072 \\
\hline
\end{tabular}

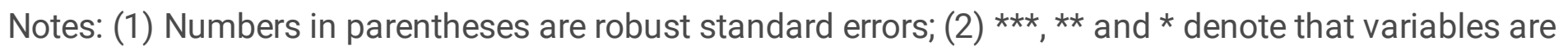
statistically significant at $1 \%, 5 \%$ and $10 \%$ respectively;(3) $\mathrm{N}$ is the number of observations and $\mathrm{R} 2$ is the goodness of fit.

The heterogeneity of openness 
The foreign direct investment (FDI) as a percentage of local GDP is used to measure a city's openness to the outside world. Samples are separated into two groups by comparing the proportion of FDI with the mean value and regression analysis is performed to both groups. Column (1) of Table 8 presents samples whose FDI proportion is greater than the average value, and their coefficient on the economic growth target is statistically significant at the $1 \%$ level; column (2) shows samples whose FDI proportion is less than or equal to the average value, and their coefficient on the economic growth target is insignificant. Accordingly, the hypothesis that a rise in economic growth targets set by local governments induces less stringent environmental regulations, only holds true in less open cities.

Table 8 Analysis of Heterogeneity II: Degree of Openness to the Outside World 
Dependent variable: environmental regulation intensity index (logarithmic form)

Low openness group

High openness group

\section{L.target}

$-0.238^{\star \star \star}$

0.065

\0.081》

\0.115】

Ipgdp

$0.193^{\star \star \star}$

$0.334^{\star \star \star}$

$\varangle 0.073 \rrbracket$

$\llbracket 0.108 \rrbracket$

Rcum

$-0.018$

0.560

『0.334】

$\triangle 0.764 \rrbracket$

Rub

0.000

0.000

0.000

0.000

Stru

$-0.008$

$-0.018^{\star \star}$

ه0.005》

$\varangle 0.008 \rrbracket$

Rfdi

0.064

0.070

\0.266》

区0.113区

ISO2

$-0.011$

0.028

(0.021)

(0.030)

Constant

$-0.428$

$-1.301$

(0.742)

(1.311)

N

967

635

R2

0.052

0.095

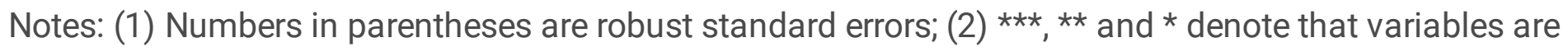
statistically significant at $1 \%, 5 \%$ and $10 \%$ respectively;(3) $\mathrm{N}$ is the number of observations and $\mathrm{R} 2$ is the goodness of fit.

To sum up, by analyzing the heterogeneity of urban development and openness of the sampled cities, this article observed that the negative effect economic growth targets on environmental regulation stringency mainly exists in cities with relatively low-level economic development and relatively low-level openness. In cities where economy is less developed and marketization of economic development is at a relatively low level, local governments tend to more actively use various government resources and approaches 
including the environmental regulations emphasized in this article, to stimulate companies to expand production capacity and to achieve high economic growth targets.

\section{Conclusion And Review}

Environmental regulation is a crucial means to deal with environmental pollution and achieve sustainable economic and social development. For local governments, environmental regulation stringency is influenced by environmental protection standards formulated by the central government, and also closely related to the regulation enforcement by local governments. The management system of economic growth targets is an important factor affecting the environmental regulation enforcement by local governments. In the performance appraisal and incentive system that centers economic growth target management, local governments often devote attention to the short-term economic benefits, and make use of the decentralization of economic, social, ecological and cultural management to deeply intervene in regional economic and social activities, including weakening the intensity of local environmental regulation, so as to achieve rapid economic growth. From the perspective of the impact of economic growth goals set by governments on economic and social development, this paper uses the 2009-2016 panel data of "China Urban Statistical Yearbook" and urban government work reports, constructs the index of environmental regulation stringency, and empirically explore the impact of economic growth targets on environmental regulation stringency.

This paper observes that high economic growth targets give rise to less stringent environmental regulation. After the robustness tests of changing measurement variables, regression samples and considering endogeneity, the conclusion is still valid, indicating that the empirical test results are robust. This paper points out that local governments aimed at achieving economic growth goals weaken environmental regulation intensity and expand outputs in the short term, which is manifested in expanding the proportion of the secondary industry in GDP, the area of land transfer and the investment in fixed assets. It is also found that the hypothesis that an increase in economic growth targets weakens environmental regulation stringency only takes effect in cities where economy is underdeveloped and openness is relatively low.

The increasingly serious environmental pollution and rapid growth of carbon emissions in China over the past four decades are closely associated with the vast expansion in the size and scale of industrial enterprises, as well as their production and operation mode of high input, high energy consumption and high output. In the "political centralization and economic decentralization" system in China, the central government has stronger political authority over local governments but grants local governments relatively strong power to manage local economic development. The evaluation and incentive mechanism for local governments and administrative officials centers economic growth target management and has played an important role in the aggravation of environmental pollution. Although the Chinese central government has been committed to strengthening the functions of the administrative departments of environmental protection, formulating and implementing a series of policies and regulations, and constantly strengthening environmental protection, little progress has been made in the environmental 
pollution treatment. This is attributed to the fact that in the assessment mechanism where management of economic growth targets (GDP) matters most, local governments tend to weaken environmental regulation stringency and enforcement in spite of the repeated orders of the central government.

\section{References}

Benoît L,Paul R (1996) Environmental Inspections and Emissions of the Pulp and Paper Industry in Quebec[J]. Journal of Environmental Economics and Management 31:19-36. https://doi.org/10.1006/jeem.1996.0029

Bo WG,Xu W,Wang JF (2018) Local Government Competition and environmental regulation heterogeneity race to the bottom or race to the top. China Soft Science 11:76-93. http://www.cqvip.com/QK/91678X/201811/676866027.html

Chen LQ,Ming G (2020) The effects of three types of China's official turnover on air quality: A regression discontinuity study[J]. Growth and Change 51(3):1081-1101. https://doi.org/10.1111/grow.12406

Chen Z, Kahn ME, Liu Y, Wang Z (2018) The consequences of spatially differentiated water pollution regulation in china[J]. Journal of Environmental Economics and Management 88(3):468-485. https://doi.org/10.1016/j.jeem.2018.01.010

Dasgupta S,Huq M, Wheeler D, Zhang CH (2001) Water pollution abatement by Chinese industry: cost estimates and policy implications[J]. Applied Economics 33(4):547-557区 https://doi.org/10.1080/00036840122068

Fu Q, Qiao Y (2011) How Government Competition Promoted China's Rapid Economic Growth: Rediscussion on the Relationship between Market Segmentation and Economic Growth[J]. The Journal of World Economy 34(07):43-63. https://doi.org/CNKI:SUN:SJJJ.0.2011-07-006

Hu S, Lv BY (2019) Economic Growth Target and Land Leasing[J]. Public Finance Research 07:46-59. https://doi.org/10.19477/j.cnki.11-1077/f.2019.07.003

Huang LX, Wang XB, Liu SL, Han YH (2015) Regional Interaction of Industrial Structure Change in China Provincial Competition in Horizontal Direction and Local Follow-up in Vertical Direction[J]. China Industrial Economics 08:82-97. https://doi.org/10.19581/j.cnki.ciejournal.2015.08.006

Jin G, Shen KR (2019) Political Incentives for Local Officials and the Diffusion of River Chief System: From the Perspective of Officials' Age[J]. Finance \& Trade Economics 40(04):20-34. https://doi.org/CNKI:SUN:CMJJ.0.2019-04-003

Lai YB (2013) The Superiority of Environmental Federalism in the Presence of Lobbying and Prior Tax Distortions[J],Journal of Public Economic Theory 15(2):341-361. https://doi.org/10.1111/jpet.12021 
Li M (2009) Causes and Countermeasures of Frequent Incidents of Environmental Damage in China-Based on the Perspective of Regional Environmental Competition[J]. Finance \& Trade Economics 000(009):82-88. https://doi.org/CNKI:SUN:CMJJ.0.2009-09-014

Li PS, Chen YY (2019) Environmental Regulation, Bargaining Power of Enterprises and Green Total Factor Productivity[J]. Finance \& Trade Economics 40(11):144-160. https://doi.org/10.19795/j.cnki.cn111166/f.20191111.006

Li SL, Chu SB, Shen C (2014) Local Government Competition, Environmental Regulation and Regional Ecological Efficiency[J]. The Journal of World Economy 04:88-110. https://doi.org/CNKI:SUN:SJJJ.0.2014-04-006

Li X,Liu C,Weng Xi, Zhou LA (2019) Target setting in tournaments: Theory and evidence from China[J]. The Economic Journal 129(623): 2888-2915. https://doi.org/10.2139/ssrn.2937195

Li YY, Shen KR (2008) Competition among Jurisdictions, Strategical Fiscal Policies, and Regional Characteristics of FDI's Growth Achievements[J]. Economic Research Journal05:58-69. https://doi.org/CNKI:SUN:JJYJ.0.2008-05-006

Lin YF, Su J (2007) On the Conversion of China's Economic Growth Mode[J]. Management World 11: 5-13. https://doi.org/10.19744/j.cnki.11-1235/f.2007.11.002

Liu DY, Xu CF,Yu YZ, Rong KZ, Zhang JY (2019) Economic growth target, distortion of public expenditure and business cycle in China[J]. China Economic Review 101373.

https://doi.org/10.1016/j.chieco.2019.101373

Liu S, Yang GQ (2019) Environmental Regulation Competition and Pollution Control[J].Journal of Capital University of Economics and Business 03:72-81. https://doi.org/10.13504/j.cnki.issn10082700.2019.02.008

Liu SL, Wang XB, Huang, LX (2019) Economic Growth Targets Drive Investment: Evidence from China's Prefecture-level Cities during 2001-2006[J].Journal of Financial Research 08:1-19. https://doi.org/CNKI:SUN:JRYJ.0.2019-08-001

Lu Y (2009) Do Environmental Regulations Influence the Competitiveness of Pollution-intensive products? [J].Economic Research Journal 04『30-42. https://doi.org/CNKI:SUN:JJYJ.0.2009-04-005

Ma L (2013) Promotion Incentive of Government Officials and Government Performance Target-setting: An Empirical Analysis of Provincial Panel Data in China[J].Journal of Public Management 10(02):28$39+138$.

Matthias, Busse (2004) Trade, Environmental Regulations and the World Trade Organization: New Empirical Evidence[J].Journal of World Trade 38:285-306. https://doi.org/10.1007/s00300-005-0106-1 
Millimet D, Fredriksson GP, List AJ (2003) Strategic competition in environmental and fiscal policies: Theory and evidence from the United States[J].Environmental Policy in an International Perspective 26:283-301. https://doi.org/10.1007/978-94-017-0333-8_13

Mitch K, Shogren FJ (2005) On Efficiency of Decentralized Environmental Regulation[J]. Journal of Regulatory Economics 28(2):129-140. https://doi.org/10.1007/s11149-005-3105-9

Oates EW (1999) An Essay on Fiscal Federalism[J]. Journal of Economic Literature 37(3):1120-1149囚 https://doi.org/10.1257/jel.37.3.1120

Oates EW, Portney RP, McGartland MA (1989) The Net Benefits of Incentive-Based Regulation: A Case Study of Environmental Standard Setting[J]. American Economic Review 79(5):1233-1242. https://doi.org/10.4324/9781315197296-12

Oates EW, Schwab MR (1988) Economic Competition among Jurisdictions: Efficiency Enhancing or Distortion Inducing?[J]. Journal of Public Economics 35(3):333-354『https://doi.org/10.1016/00472727(88)90036-9

Ren L, Matsumoto K (2020) Effects of socioeconomic and natural factors on air pollution in China: A spatial panel data analysis[J]. Science of The Total Environment 740. https://doi.org/10.1016/j.scitotenv.2020.140155

Ren SG, Li XL, Yuan BL, Li DY, Chen XH (2018) The effects of three types of environmental regulation on eco-efficiency: A cross-region analysis in China[J]. Journal of Cleaner Production 173:245-255. https://doi.org/10.1016/j.jclepro.2016.08.113

Stavins NR (2007) Environmental Economics[D]. NBER Working paper 13574. https://doi.org/10.2139/ssrn.647665

Sun WK, Liu YC (2016) The Effect of Economic Target of Goverment--Evidence from China[J].Economic Theory and Business Management 03:5-13. https://doi.org/10.3969/j.issn.1000-596X.2016.03.001

Tao H, Yu NN, Mao ZG (2019) Does environment centralization prevent local governments from racing to the bottom? -Evidence from China[J].Journal of Cleaner Production 231:649-659.

https://doi.org/10.1016/j.jclepro.2019.05.181

Timothy A, Anne C (1995) Does Electoral Accountability Affect Economic Policy Choices? Evidence from Gubernatorial Term Limits[J]. Quarterly Journal of Economics 3:769-798.

https://doi.org/10.2307/2946699

Tu HX, Chen J (2019) Empirical Study on the Effect of Environmental Regulation on Technological Innovation of Cement Industry in China[J]Journal of Hubei Polytechnic University(Humanities and Social Sciences) 01:44-53. 
Tung S, Cho S (2001) Determinants of Regional Investment Decisions in China: An Econometric Model of Tax Incentive Policy[J]. Review of Quantitative Finance \& Accounting 17(2):167-185.

https://doi.org/10.1023/A:1017925721627

Wang HS, Wang YG (2009) Target Management Responsibility System:The Practical Logic of Local Party-State in Rural China[J]. Sociological Studies 24(02):61-92+244.

https://doi.org/CNKI:SUN:SHXJ.0.2009-02-008

Wang L, Kong DM, Dai YH (2018) Politicians' Promotion Pressure and Firm Innovation[J].Journal of Management Sciences in China 21(01):111-126. https://doi.org/10.3969/j.issn.1007-9807.2018.01.009

Wang XB, Huang LX (2019) Local Economic Growth Target Management--A Triple-factor Framework of Theoretical Construction and Empirical Test[J].Economic Theory and Business Management 09:30-44. https://doi.org/CNKI:SUN:JJLL.0.2019-09-004.

Wang XB, Xu XX (2010) Research on the Track and Mechanism of China's Local Official Economic Growth[J]. Economist 11:34-43. https://doi.org/CNKI:SUN:JJXJ.0.2010-11-007

Wang XH, Yang Q, He N (2020) Research on the Influence of Environmental Regulation on Social Employment-An Empirical Analysis Based on the STR Model[J].International Journal of Environmental Research and Public Health 17(2). https://doi.org/10.3390/ijerph17020622

Wang YL (2013) The Transformation of the Dynamic Mechanism of China's Economic Growth[J].Theory Monthly 06:131-135. https://doi.org/10.3969/j.issn.1004-0544.2013.06.029

Wang ZH, Chao F (2014) The impact and economic cost of environmental regulation on energy utilization in China[J]. Applied Economics 46(27):3362-3376. https://doi.org/10.1080/00036846.2014.929629

Wang ZL, Xia C, Xia YH (2020) Dynamic relationship between environmental regulation and energyconsumption structure in Chinaunder spatiotemporal heterogeneity[J]. Science of The Total Environment 738. https://doi.org/ 10.1016/j.scitotenv.2020.140364

Wayne BG, Deliy ME (1996) Compliance and Enforcement: Air Pollution Regulation in the U.S. Steel Industry[J].Journal of Environmental Economics and Management 31: 96-111.

https://doi.org/10.1006/jeem.1996.0034

Xin Lu, Luo SG (2020) Research on the Lag Effect of Economic Growth Caused by Scientific and Technological Innovation Based on Provincial Panel Data[J].Modernization of Management 40(03):39-42. https://doi.org/10.19634/j.cnki.11-1403/c.2020.03.011

Xiong Y (2011) Research on the Relationship Between Environmental Regulation and Economic Growth Based on the Provincial Data in China[J].China Population, Resources and Environment 021(005):126131. https://doi.org/10.3969/j.issn.1002-2104.2011.05.021 
Xu XX, Gao YH (2015) Growth target management and regional economic growth[J].Journal of The Asia Pacific Economy 20(3):517-534. https://doi.org/10.1080/13547860.2015.1054172

Xu XX, Li Sj, Wang XB, Bi QM (2018) Growth Target Choices:Ending Chinese Collapse Fallacy with HighQuality Development[J].The Journal of World Economy 41(10):3-25.

https://doi.org/CNKI:SUN:SJJJ.0.2018-10-002

Xu XX, Liang JX (2014) Strategical Adjustment of Growth Target.[J].Economic Research Journal 49(01):27-40. https://doi.org/CNKI:SUN:JJYJ.0.2014-01-013

Xu XX, Liu YY (2017) Economic Growth Target Management[J].Economic Research Journal 52(07):18-33. https://doi.org/CNKI:SUN:JJYJ.0.2017-07-003

Yana R, Marzio G, Elena V (2015) Environmental regulation and competitiveness: Empirical evidence on the Porter Hypothesis from European manufacturing sectors[J]. Energy Policy 83:288-300.

https://doi.org/10.1016/j.enpol.2015.02.014

Yang HS, Chen SL, Zhou YI (2008) Local Government Competition and Environmental Policy--Empirical Evidence from Province's Governments in China[J]South China Journal of Economics 000(006):15-30. https://doi.org/10.3969/j.issn.1000-6249.2008.06.002

Yu LY, Tian W, Xing HZ (2020) Impact of environmental regulations on economic development[C]. 2020 International Conference on Urban Engineering and Management Science (ICUEMS)

Yu YZ, Pan Y (2019) The Mysterious Coexistence of Rapid Economic Growth and a Lag in the Service Industry's Upgrade in China: An Interpretation Based on the Economic Growth Target Constraints Perspective[J]Economic Research Journal 54(03):150-165.https://doi.org/CNKI:SUN:JJXD.0.2017-02-006

Yu YZ, Yang XZ (2017) Official Tenure, Official Characteristics and Economic Growth Target Setting-Empirical Evidence From 230 Prefecture-level Cities[J].Economic Perspectives 02:51-65.

Zeng WH (2008) Regulation on Trans-boundary Water Pollution:A Study on Inter-judiciary River-basin Pollution in China[J].China Economic Quarterly 02:447-464. https://doi.org/CNKI:SUN:JJXU.0.2008-02004

Zhang C, Yu TS, Guo Lu (2010) Does Envenronmental Regulation Influence Industrial Productivity in China--The Empirical Test Based on DEA and Co-integration Analysis[J].Economic Theory and Business Management 03:13-19.

Zhang HM, Xiong LF, Qiu YM, Zhou DQ (2017) How Have Political Incentives for Local Officials Reduced the Environmental Pollution of Resource-depleted Cities?[J]. Energy Procedia 143:873-879. https://doi.org/10.1016/j.egypro.2017.12.776 
Zhang J (2005) China's Economic Development: Competing for Growth[J].World Economic Papers Z1:101-105. https://doi.org/10.3969/j.issn.0488-6364.2005.04.017

Zhang L, Gao YH, Xu XX (2013) Land Transfer Under the Collusion of Government and Enterprise[J].Management World 12:43-51+62. https://doi.org/CNKI:SUN:GLSJ.0.2013-12-006

Zhang P (2020) Target Interactions and Target Aspiration Level Adaptation: How Do Government Leaders Tackle the "Environment-Economy" Nexus? [J]. Public Administration Review 2. https://doi.org/10.1111/puar.13184

Zhang X, Chen ZG (2018) Economic Growth Incentive,Local Officials' Characteristics and Urban Industrial Pollution:A Case Study of the Yangtze River Delta[J].Resources and Environment in the Yangtze Basin

Zhang XG (2020) Current Situation and Trend of Environmental Regulation Intensity Measurement[J].Environment and Development 32(07):4-5+10. https://doi.org/10.13502/j.cnki.issn10007636.2017.08.008

Zhang ZB, Jin TJ, Meng XH (2020) From race-to-the-bottom to strategic imitation: how does political competition impact the environmental enforcement of local governments in China?[J].Environmental Science and Pollution Research 27(20):25675-25688. https://doi.org/10.1007/s11356-020-09003-9

Zhao C, Kahn ME, Liu Y, Wang Z (2018)The consequences of spatially differentiated water pollution regulation in china[J].Journal of Environmental Economics and Management 88(3):468-485. https://doi.org/10.1016/j.jeem.2018.01.010

Zhao H (2007) Empirical Study on the Impact of Environmental Regulation on Industrial Technological Innovation of China[J].Business Management Journal 21:57-61. https://doi.org/CNKI:SUN:JJGU.0.200721-015

Zhou L (2007)Governing China's Local Officials:An Analysis of Promotion Tournament Model[J].Economic Research Journal 07:36-50. https://doi.org/CNKI:SUN:JJYJ.0.2007-07-006

Zhou L, Liu C, LI X, Wen X (2015) "Overweight" and Officials' Incentives[J].World Economic Papers 01:115. https://doi.org/CNKI:SUN:SZWH.0.2015-01-001

Zhou M, Bi RG, Kou ZL (2017) Official tenure, age limit and local firm investment:evidence from listed companies in China[J].Industrial Economics Research 03:116-126.

https://doi.org/10.13269/j.cnki.ier.2017.03.010

Zhou Y, Zhu SJ, He CF (2017) How do environmental regulations affect industrial dynamics? Evidence from China's pollution-intensive industries[J]. Habitat International 60:10-18.

https://doi.org/10.1016/j.habitatint.2016.12.002 
Zhu PF, Zhang ZY, Jiang GL (2011) Empirical Study of the Relationship between FDI and Environmental Regulation:An Intergovernmental Competition Perspective[J].Economic Research Journal 06:134-146. https://doi.org/CNKI:SUN:JJYJ.0.2011-06-013 